\title{
Effects of glucagon on in vitro liquid production by lungs from fetal guinea pigs
}

N Choo, A L Liu, A M Perks

\begin{abstract}
Background-Lung liquid reabsorption in newborns with respiratory distress syndrome can be deficient. Respiratory distress syndrome is often seen in infants of diabetic mothers, in whom the neonatal surge of glucagon is suppressed.
\end{abstract}

Aim-To investigate the possible effects of glucagon on lung liquid reabsorption.

Methods-Lungs from near term fetal guinea pigs (62 (2) days gestation; term $=67$ days) were supported in vitro for three hours; lung liquid production and reabsorption were monitored by a dye dilution method.

Results-Untreated control preparations produced fluid at $1.75(0.33) \mathrm{ml} / \mathrm{h}$ per $\mathrm{kg}$ body weight, and did not change significantly in three hours; those immersed in $10^{-12} \mathrm{M}$ glucagon during the middle hour showed no significant change, but those given higher concentrations all showed significant reductions in fluid production or even reabsorption $(65.6(10.3) \%$ fall at $10^{-11} \mathrm{M}, 70.0(6.3) \%$ fall at $10^{-10} \mathrm{M}$, and 90.6 (11.1)\% fall at $10^{-9} \mathrm{M}$; based on 54 preparations). At $10^{-9} \mathrm{M}$ glucagon, 12 out of 30 preparations reabsorbed fluid. The linear log dose-response curve $\left(r^{2}=0.94\right)$ gave a theoretical threshold at $4 \times 10^{-15} \mathrm{M}$ glucagon. Responses appeared to involve the amiloride sensitive $\mathrm{Na}^{+}$based reabsorptive system: responses to $10^{-9} \mathrm{M}$ glucagon appeared to be reduced by $10^{-6} \mathrm{M}$ amiloride, and were abolished by $10^{-5} \mathrm{M}$ amiloride (based on 72 preparations).

Conclusions-The results suggest that the surge of glucagon at birth may help to drain the lungs of fluid. As glucagon liberates CAMP, which also stimulates surfactant, glucagon is worth consideration for possible use in neonatal respiratory distress.

(Arch Dis Child Fetal Neonatal Ed 2000;83:F28-F34)

Keywords: glucagon; fetus; lung liquid; guinea pig; respiratory distress syndrome

Departments of Obstetrics and Gynecology and Zoology, University of British Columbia Vancouver, BC, Canada V6H 3V5 N Choo

A L Liu

A M Perks

Correspondence to: Dr Perks, Department of Obstetrics and Gynecology, Faculty of Medicine, Room 2H30, 4490 Oak Street, Vancouver, BC, Canada V6H 3V5

Accepted 17 November 1999

It is vital to clear the lungs of fluid at the time of birth. Up to that time, fluid has been actively secreted by a $\mathrm{Cl}^{-}$based mechanism $\left(\mathrm{Na}^{+} / \mathrm{K}^{+}\right)$ $2 \mathrm{Cl}^{-}$cotransport), probably present in pulmonary type II cells. ${ }^{1}$ At birth, this is replaced by a $\mathrm{Na}^{+}$based reabsorptive system, at least partly dependent on amiloride sensitive $\mathrm{Na}^{+}$channels present in the apical membranes of type II cells. ${ }^{12}$ The mechanisms that produce this change are probably numerous, as the process is vital to the newborn, and each influence forms an insurance for failure of the others.
Despite this, failures do occur; they are seen in situations related to hypoxia, ${ }^{2}$ prematurity, and caesarean section, ${ }^{3}$ and, most significantly, in respiratory distress syndrome, a major cause of newborn death. ${ }^{4}$

The factors that can reverse fluid movement at birth fall into four main categories: hormonal (adrenaline, ${ }^{1}$ arginine vasopressin (AVP) ${ }^{5}$ adrenal steroids ${ }^{6}$ ); physical (expansion of the lungs, ${ }^{7}$ fall in temperature, ${ }^{8}$ ); paracrine (products of the neuroendocrine system of the lungs ${ }^{9-11}$ ); neural (acetyl choline, ${ }^{12}$ noradrenaline $\left.\mathrm{e}^{13}\right)$. Although a variety of second messengers may be involved, at least two of the hormones are known to act through the adenylate cyclase system (adrenaline and $\beta$-agonists, ${ }^{14} \mathrm{AVP}^{15}$ ), and cAMP, its analogues, and forskolin are known to produce fluid reabsorption. ${ }^{16}$ Therefore it seemed reasonable that other activators of adenylate cyclase may also produce fluid reabsorption.

Glucagon has held a special place in our understanding of the adenylate cyclase system. It was studies of its mode of action that first uncovered cAMP, and it is known to be a powerful activator of this system. ${ }^{17}{ }^{18}$ It is also known to surge to high plasma levels immediately after birth in every species tested, including man (rat, ${ }^{19}$ rabbit, ${ }^{20}$ sheep, ${ }^{21}$ human $^{22}$ ). In addition, glucagon receptors are found in lungs, surprising for a hormone mainly associated with carbohydrate metabolism in the liver, and transcripts of their mRNA are found in unusually high levels in lungs of fetal and young animals. ${ }^{23} 24$ Although the functions of these receptors are not known, Campos et $a l^{4}$ suggested, perhaps with notable insight, that they may be concerned with functions in the fetal lung, rather than actions in the adult. ${ }^{24}$ Clearly, there were many indications that glucagon may be involved in drainage of the newborn lung, but no studies were ever made.

In the work presented here, glucagon is shown to be capable of activating fluid reabsorption in vitro by lungs from fetal guinea pigs, a new observation that may have useful consequences.

\section{Materials and methods}

ANIMALS

Pregnant albino guinea pigs of an inbred departmental stock were given food and water ad libitum (guinea pig chow, Ralston-Purina, supplemented with fresh vegetables and vitamin C). Treatment of the animals was in accordance with the Canadian Council for Animal Care, and in conditions approved by the animal care committee of the University of British Columbia. Studies were performed on 
fetuses of 62 (2) days gestation (term $=67$ days) and 89.6 (18.9) g body weight (means (SD)).

EXPERIMENTAL PROCEDURES

Methods for measuring rates of lung liquid production and reabsorption have been detailed and confirmed for validity in previous publications. ${ }^{122526}$ In brief, lung liquid production or reabsorption was measured by an impermeant tracer technique based on Blue Dextran 2000 (Pharmacia, Dorval, Que, Canada). Pregnant guinea pigs were anaesthetised with halothane, and the fetuses removed by caesarean section. The trachea of each fetus was cannulated towards the lungs with polyethylene tubing filled with saline and connected to a $1.0 \mathrm{ml}$ tuberculin reservoir syringe. The lungs were removed and supported in baths of Krebs-Henseleit saline at $37^{\circ} \mathrm{C}$ bubbled with $95 \% \mathrm{O}_{2}$ and $5 \% \mathrm{CO}_{2}$. Then 100 $\mu 1$ Blue Dextran $2000(50 \mathrm{mg} / \mathrm{ml}$ in $0.9 \%$ $\mathrm{NaCl}$ ) was mixed into the lung liquid, and the preparations were equilibrated for 30 minutes. During the experimental period (three hours), lung liquid was withdrawn into the reservoir syringe every 10 minutes, and $10 \mu \mathrm{l}$ samples were removed with a $1701 \mathrm{NCH}$ gas tight fixed volume syringe (Hamilton Co, Reno, Nevada, USA). These samples were diluted 1:20 with distilled water, vortex mixed, and centrifuged for 10 minutes at $250 \mathrm{~g}$; Blue Dextran in the supernatants was estimated by spectrophotometry $(\lambda=620 \mathrm{~nm})$. Throughout the experiment, proper mixing of dye within the lungs was ensured by withdrawing and returning 0.3 $\mathrm{ml}$ of lung liquid into the reservoir syringe every five minutes and by the gentle but continuous movements of the lungs in the bubbled saline. The experiments followed an ABA design. Samples taken during the first hour after equilibration gave the resting rate of fluid production. The lungs, still attached to their reservoir syringe, were then transferred to fresh Krebs-Henseleit saline which contained one of the following: (a) synthetic glucagon at $10^{-12}, 10^{-11}, 10^{-10}$, or $10^{-9} \mathrm{M}$; (b) $10^{-9} \mathrm{M}$ glucagon with $10^{-6} \mathrm{M}$ amiloride hydrochloride (amiloride was placed in both the outer saline (basally) and the lung fluid (apically)); (c) $10^{-9}$ $\mathrm{M}$ glucagon with $10^{-5} \mathrm{M}$ amiloride hydrochloride used in the same way; (d) $10^{-6}$ or $10^{-5} \mathrm{M}$ amiloride hydrochloride alone, used as before; (e) Krebs-Henseleit saline with no drugs (untreated controls (these controls received changes of saline on each hour, as for experimental lungs). Amiloride was placed both inside and outside the preparations in order to remove the concentration gradient, which would have caused loss from the apical side of the epithelium. All reagents were from Sigma (St Louis, MO, USA).

In all experiments, the preparations were transferred back to Krebs-Henseleit saline for the final hour.

\section{QUANTIFICATION OF RESULTS AND STATISTICAL} METHODS

The rates of fluid production were calculated from the fall in concentration of Blue Dextran, as described previously. ${ }^{25}{ }^{26}$ Rates were estimated from plots of the total volume of fluid against time, with readings recorded every 10 minutes; the total volume of fluid was the sum of that within the lungs and that removed for study. Appropriate sequential adjustments were made every 10 minutes for removal of both fluid and Blue Dextran during incubation. The rates of production of fluid over one hour intervals were calculated from the volume plots, using the slopes of their regressions, fitted by the method of least squares (HewlettPackard program SD-03A, or Apple II Plus computer). In groups of similar experiments, differences in rates in successive hours were analysed by analysis of variance and NewmanKeul's test (ANOVA). When plots from similar experiments were combined, the volumes were expressed as a percentage of the volume present at the end of the first hour, just before transfer to test solutions or fresh control saline; the values were then averaged. ${ }^{25}{ }^{26}$ The significance of changes in rate were also assessed from the combined graphs by submitting the changes in slopes to a test for differences between two regressions (regression analysis ${ }^{25}{ }^{26}$; this test used all values for volumes from all experiments in the group. Whereas both ANOVA and regression analysis considered the magnitude of the changes seen, ANOVA took into consideration the repeatability of the responses, and regression analysis allowed for scatter around the lines of best fit, a variability not included in ANOVA. All mean values are given with their standard errors, unless otherwise indicated. Statistical significance was accepted at or below $\mathrm{p}=0.05$.

\section{Results}

EFFECTS OF GLUCAGON ON LUNG LIQUID PRODUCTION IN VITRO

Basic studies were carried out on 54 in vitro preparations of lungs from fetal guinea pigs of 62 (2) days gestation and 90.2 (18.8) g body weight (means (SD)). Initially, 30 preparations were divided into groups of six, but data from those given $10^{-9} \mathrm{M}$ glucagon were supplemented with results from later studies. During the middle hour of the three hour incubations, the preparations received $10^{-12}, 10^{-11}, 10^{-10}$, or $10^{-9} \mathrm{M}$ glucagon, or saline alone (untreated controls). Figure 1 shows the results, and table 1 the significance of changes.

Six untreated (control) preparations and six given $10^{-12} \mathrm{M}$ glucagon continued to produce fluid with no significant change (ANOVA; regression analysis) (fig $1 \mathrm{~A}, \mathrm{~B}$ respectively). Six lungs given $10^{-11} \mathrm{M}$ glucagon all reduced production, and one showed reabsorption: the average reduction of 65.6 (10.3)\% was significant by both statistical tests (fig 1C). Greater and significant reductions were shown by all preparations at higher concentrations of hormone: average reductions were $70.0(6.3) \%$ at $10^{-10} \mathrm{M}$ glucagon and $90.6(11.1) \%$ at $10^{-9} \mathrm{M}$ glucagon (fig 1D,E). At the highest concentration, 12 of the 30 preparations turned to reabsorption. Good or partial recoveries were found in all groups after removal of glucagon. Responses quantified as percentage reductions 


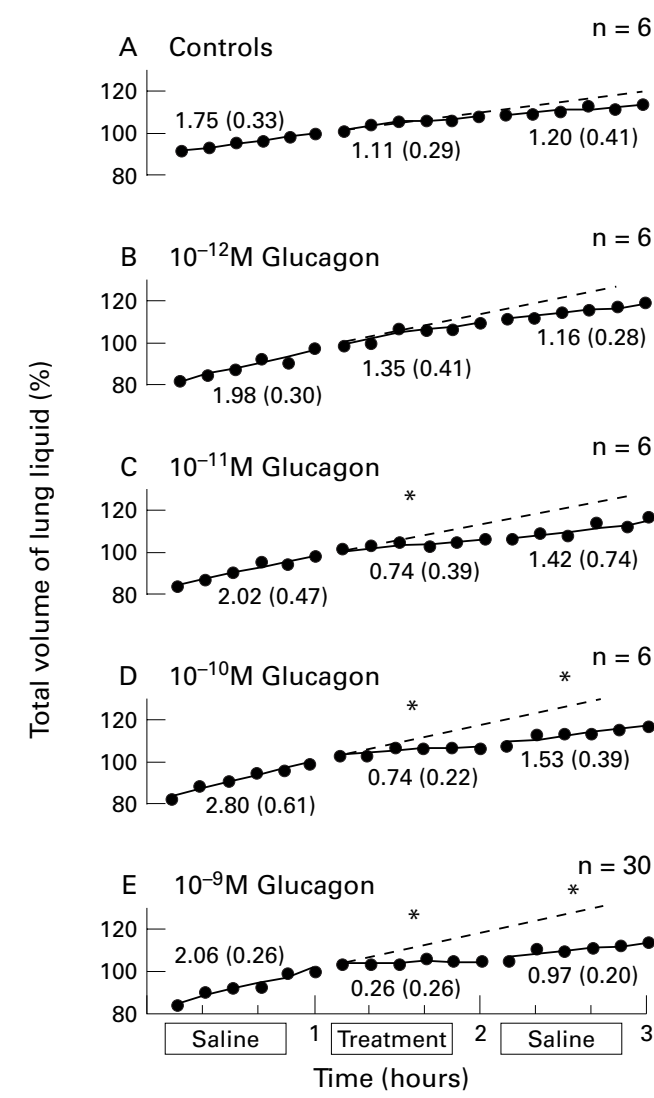

Figure 1 Effects of glucagon on in vitro liquid production by lungs from fetal guinea pigs. Based on 54 fetuses of 62 (2) days gestation and $90.2(18.8) \mathrm{g}$ body weight. During the middle hour, the preparations were immersed in saline containing one of the following: $(A)$ saline alone (untreated preparations); (B) $10^{-12} \mathrm{M}$ glucagon; (C) $10^{-11} \mathrm{M}$ glucagon; (D) $10^{-10} \mathrm{M}$ glucagon; (E) $10^{-9} \mathrm{M}$ glucagon. Ordinates: total volume of lung liquid expressed as a percentage of that present at the end of the first hour, where $100 \%$ was: (A) $1.15(0.17) \mathrm{ml} ;(B) 0.75(0.13) \mathrm{ml} ;(C)$ $1.05(0.49) \mathrm{ml}$; (D) $1.36(0.77) \mathrm{ml}$; (E) $1.04(0.40) \mathrm{ml}$; all means (SD). All regressions are lines of best fit; slopes represent production rates. Values below the lines are mean (SEM) production rates in $\mathrm{ml} / \mathrm{h}$ per $\mathrm{kg}$ body weight. Asterisks above the lines show significant changes from the original slope (dashed lines). Standard errors are omitted for clarity, but they averaged: (A) 1.41 (0.18); (B) 2.74 (0.27); (C) 3.67 (0.50); (D) $2.90(0.22)$; (E) 2.01 $(0.22)$. Corresponding coefficients of variation were: $(A)$ $1.65(0.39) \%$, (B) $9.44(0.93) \%$; (C) 8.23 (1.94)\%;

(D) $6.75(0.52) \%$; (E) $10.50(1.00) \%$.

during treatment showed a linear relation with $\log$ dose $\left(r^{2}=0.94\right)$, with a theoretical threshold at $4 \times 10^{-15} \mathrm{M}$ glucagon (fig 2). Over the groups studied, there was no relation between response and age or weight; however, in additional tests of four fetuses below $65 \mathrm{~g}$ body weight, two failed to respond.

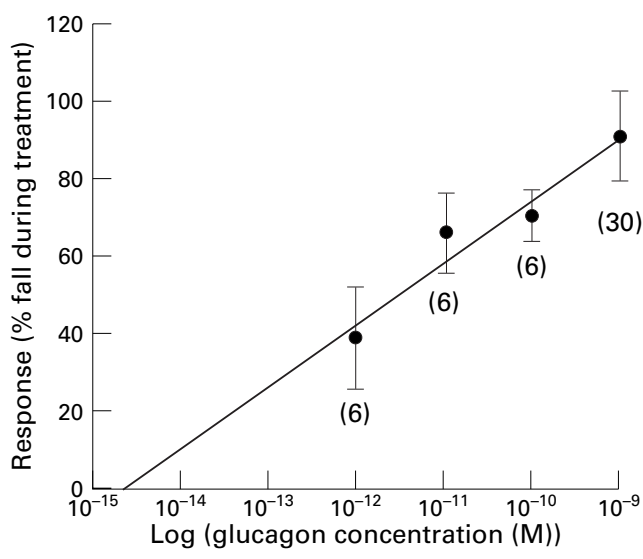

Figure 2 Log dose-response curve for effects of glucagon on in vitro liquid production by lungs from fetal guinea pigs. Based on 48 fetuses of 62 (2) days gestation and 91.8 (18.9) g body weight. Ordinate: responses quantified as percentage falls in production between the hour before and the hour during treatment; error bars represent SEM, and the numbers of fetuses are given below the bars. Abscissa: concentrations of glucagon (M) on a log scale.

EFFECTS OF $10^{-6} \mathrm{M}$ AMILORIDE

Amiloride was used to determine whether glucagon acted through the amiloride sensitive $\mathrm{Na}^{+}$based reabsorptive system activated by other agents.

Initial studies were made on 36 preparations of in vitro lungs from fetal guinea pigs of 61 (2) days gestation and 93.1 (17.3) g body weight. They were divided into three groups of 12 lungs: one group received $10^{-9} \mathrm{M}$ glucagon alone, one group received $10^{-9} \mathrm{M}$ glucagon together with $10^{-6} \mathrm{M}$ amiloride, and one group formed the controls (six with $10^{-6} \mathrm{M}$ amiloride alone, and six with saline only (untreated controls)). Figure 3 shows the results, and table 2 the significances of changes.

Amiloride at a concentration of $10^{-6} \mathrm{M}$ reduced, but did not abolish, responses to glucagon. In these studies, $10^{-9} \mathrm{M}$ glucagon caused significant reductions in fluid production in all 12 preparations, with eight turning to reabsorption; the average reduction was large (130.4 (21.1)\% fall: fig 3A). When $10^{-9} \mathrm{M}$ glucagon was tested in the presence of $10^{-6} \mathrm{M}$ amiloride, three preparations showed no response; however, six still reduced production, and three turned to reabsorption; the average reduction was still significant, but had halved to 67.5 (18.9)\% (fig 3B). Comparison of percentage reductions with and without amiloride showed that the responses were significantly reduced in the presence of the channel blocker (ANOVA: $p<0.05$ ). Preparations given $10^{-6} \mathrm{M}$ amiloride alone and untreated

Table 1 Effects glucagon on lung liquid production

\begin{tabular}{|c|c|c|c|c|c|c|c|c|c|c|}
\hline \multirow[b]{2}{*}{$\begin{array}{l}\text { Concentration of } \\
\text { glucagon }(M)\end{array}$} & \multirow[b]{2}{*}{$n$} & \multicolumn{3}{|c|}{$\begin{array}{l}\text { Rate of production of lung liquid } \\
\text { (ml/h per } \mathrm{kg} \text { body weight) }\end{array}$} & \multicolumn{2}{|c|}{$\begin{array}{l}\text { Reductions from the hour before } \\
\text { treatment (ml/h per kg body weight) }\end{array}$} & \multicolumn{2}{|c|}{$\begin{array}{l}\text { Significance of reductions } \\
\text { during treatment ( } p \text { value) }\end{array}$} & \multicolumn{2}{|c|}{$\begin{array}{l}\text { Significance of reductions } \\
\text { after treatment }(P)\end{array}$} \\
\hline & & $\begin{array}{l}\text { Hour before } \\
\text { treatment }\end{array}$ & $\begin{array}{l}\text { Hour during } \\
\text { treatment }\end{array}$ & $\begin{array}{l}\text { Hour after } \\
\text { treatment }\end{array}$ & $\begin{array}{l}\text { Hour during } \\
\text { treatment }\end{array}$ & $\begin{array}{l}\text { Hour after } \\
\text { treatment }\end{array}$ & ANOVA & $\begin{array}{l}\text { Regression } \\
\text { analysis }\end{array}$ & ANOVA & $\begin{array}{l}\text { Regression } \\
\text { analysis }\end{array}$ \\
\hline 0 (controls) & 6 & $1.75(0.33)$ & $1.11(0.29)$ & $1.20(0.14)$ & $0.64(0.29)$ & $0.55(0.22)$ & $>0.05$ & $>0.05$ & $>0.05$ & $>0.05$ \\
\hline $10^{-12}$ & 6 & $1.98(0.30)$ & $1.35(0.41)$ & $1.16(0.28)$ & $0.63(0.24)$ & $0.82(0.30)$ & $>0.05$ & $>0.05$ & $>0.05$ & $>0.05$ \\
\hline $10^{-11}$ & 6 & $2.02(0.47)$ & $0.74(0.39)$ & $1.42(0.74)$ & $1.28(0.57)$ & $0.60(0.41)$ & $<0.05$ & $<0.025$ & $>0.05$ & $>0.05$ \\
\hline $10^{-10}$ & 6 & $2.80(0.61)$ & $0.74(0.22)$ & $1.53(0.39)$ & $2.06(0.48)$ & $1.27(0.38)$ & $<0.005$ & $<0.01$ & $<0.025$ & $<0.05$ \\
\hline $10^{-9}$ & 30 & $2.06(0.26)$ & $0.26(0.26)$ & $0.97(0.20)$ & $1.80(0.28)$ & $1.09(0.03)$ & $<0.001$ & $<0.0005$ & $>0.05$ & $<0.01$ \\
\hline
\end{tabular}

All values are mean (SEM). 

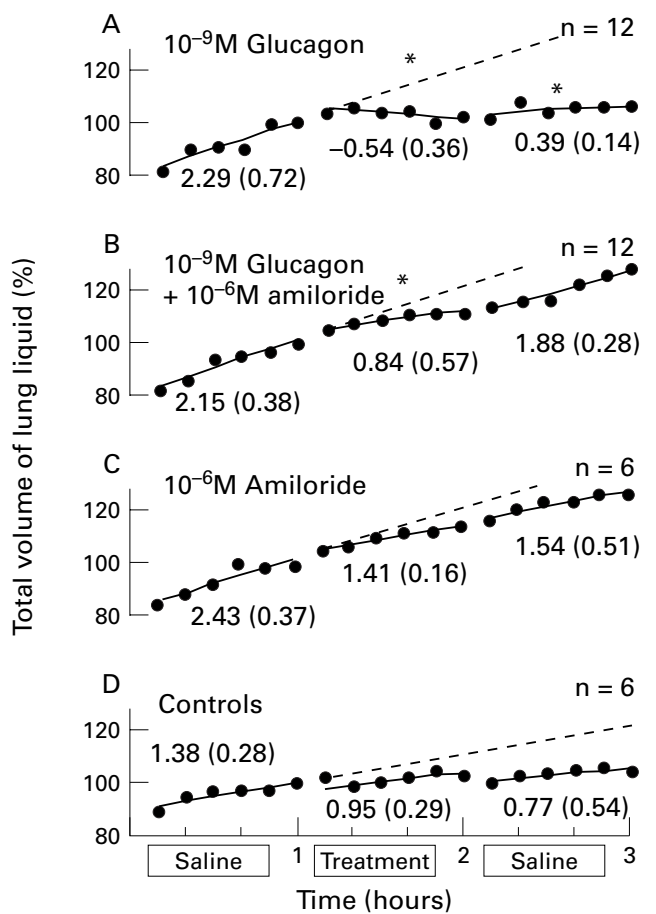

Figure 3 Effect of $10^{-6} \mathrm{M}$ amiloride on in vitro responses to glucagon by lungs from fetal guinea pigs. Based on 36 fetuses of 61 (2) days gestation and 93.1 (17.3) g body weight. During the middle hour, the preparations were immersed in saline containing one of the following: (A) $10^{-9}$ $\mathrm{M}$ glucagon alone; (B) $10^{-9} \mathrm{M}$ glucagon with $10^{-6} \mathrm{M}$ amiloride; (C) $10^{-6} \mathrm{M}$ amiloride alone; (D) saline alone (untreated controls). Ordinates: total volume of lung liquid expressed as a percentage of that present at the end of the first hour, where $100 \%$ was: (A) 0.85 (0.22) $\mathrm{ml}$; (B) 0.81 (0.10) ml; (C) 1.20 (0.31) ml, (D) 1.09 (0.24) ml; all means (SD). All regressions are lines of best fit; slopes represent production rates. Values below the lines are mean (SEM) production rates in $\mathrm{ml} / \mathrm{h}$ per $\mathrm{kg}$ body weight. Asterisks above the lines show significant changes from the original slope (dashed lines). Standard errors are omitted for clarity, but they averaged: (A) 2.64 (0.23); (B) 2.58 (0.24); (C) 5.87 (0.62); (D) 2.61 (0.28). Corresponding coefficients of variation were: (A) $9.06(0.73) \%$; (B) 8.19 (0.76)\%; (C) 12.69 (1.16)\%; (D) $6.39(0.68) \%$.

controls showed no significant changes (fig 3C,D).

EFFECTS OF $10^{-5} \mathrm{M}$ AMILORIDE

As only partial reductions were seen with $10^{-6}$ $\mathrm{M}$ amiloride, the concentration was increased to $10^{-5} \mathrm{M}$. Studies were made on 36 preparations from guinea pigs of 63 (2) days gestation and 94.5 (19.7) g body weight. They were divided into the same groups as used previously. Figure 4 shows the results, and table 2 the significances of changes.

At a concentration of $10^{-5} \mathrm{M}$, amiloride abolished responses to glucagon. Glucagon at
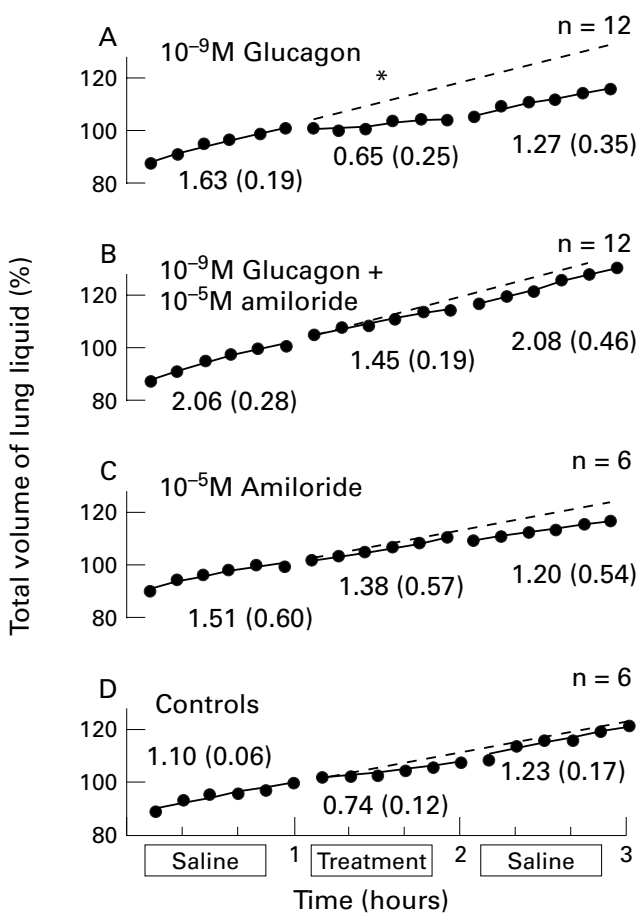

Figure 4 Effect of $10^{-5} \mathrm{M}$ amiloride on in vitro responses to glucagon by lungs from fetal guinea pigs. Based on 36 fetuses of 63 (2) days of gestation and 94.5 (19.7) g body weight. During the middle hour, the preparations were immersed in saline containing one of the following: $(A) 10^{-9}$ $\mathrm{M}$ glucagon alone; (B) $10^{-9} \mathrm{M}$ glucagon with $10^{-5} \mathrm{M}$ amiloride; (C) $10^{-5} \mathrm{M}$ amiloride alone; (D) saline alone (untreated controls). Ordinates: total volume of lung liquid expressed as a percentage of that present at the end of the first hour, where $100 \%$ was: (A) 1.10 (0.38) $\mathrm{ml}$; (B) 1.25 (0.24) $\mathrm{ml} ;(C) 0.83$ (0.18) $\mathrm{ml}$; (D) 0.96 (0.24) $\mathrm{ml}$; all means (SD). All regressions are lines of best fit; slopes represent production rates. Values below the lines are mean (SEM) production rates in $\mathrm{ml} / \mathrm{h}$ per $\mathrm{kg}$ body weight.

Asterisks above the lines show significant changes from the original slope (dashed lines). Standard errors are omitted for clarity, but they averaged: (A) 1.37 (0.17); (B) 2.52 (0.29); (C) $1.90(0.34)$; (D) 1.74 (0.21). Corresponding coefficients of variation were: (A) $2.19(0.52) \%$; (B) 7.87 (0.76)\%; (C) 4.28 (0.71)\%; (D) $3.96(0.43) \%$.

$10^{-9} \mathrm{M}$ produced the usual significant effects, with 10 preparations reducing production and two turning to reabsorption (fig 4A). In the presence of $10^{-5} \mathrm{M}$ amiloride, there was no longer any significant reduction in production (ANOVA; regression analysis; fig 4B). ANOVA also showed that the percentage changes with and without amiloride were significantly different from one another $(\mathrm{p}<0.01)$. Preparations given $10^{-5} \mathrm{M}$ amiloride alone and untreated controls showed no significant changes (fig 4C,D).

It was concluded that the largest responses produced by glucagon could be reduced by

Table 2 Effects of amiloride on responses to glucagon

\begin{tabular}{|c|c|c|c|c|c|c|c|c|c|c|c|}
\hline \multirow[b]{2}{*}{$\begin{array}{l}\text { Concentration } \\
\text { of glucagon } \\
\text { (M) }\end{array}$} & \multirow[b]{2}{*}{$\begin{array}{l}\text { Concentration } \\
\text { of amiloride } \\
\text { (M) }\end{array}$} & \multirow[b]{2}{*}{$n$} & \multicolumn{3}{|c|}{$\begin{array}{l}\text { Rate of lung liquid production }(\mathrm{m} / \mathrm{h} \text { per } \mathrm{kg} \\
\text { body weight) }\end{array}$} & \multicolumn{2}{|c|}{$\begin{array}{l}\text { Reductions from the hour before } \\
\text { treatment (ml/h per kg body weight) }\end{array}$} & \multicolumn{2}{|c|}{$\begin{array}{l}\text { Significance of reductions } \\
\text { during treatment ( } p \text { value) }\end{array}$} & \multicolumn{2}{|c|}{$\begin{array}{l}\text { Significance of reductions } \\
\text { after treatment }(P)\end{array}$} \\
\hline & & & $\begin{array}{l}\text { Hour before } \\
\text { treatment }\end{array}$ & $\begin{array}{l}\text { Hour during } \\
\text { treatment }\end{array}$ & $\begin{array}{l}\text { Hour after } \\
\text { treatment }\end{array}$ & $\begin{array}{l}\text { Hour during } \\
\text { treatment }\end{array}$ & $\begin{array}{l}\text { Hour after } \\
\text { treatment }\end{array}$ & ANOVA & $\begin{array}{l}\text { Regression } \\
\text { analysis }\end{array}$ & ANOVA & $\begin{array}{l}\text { Regression } \\
\text { analysis }\end{array}$ \\
\hline $10^{-9}$ & 0 & 24 & $1.72(0.14)$ & $0.05(0.29)$ & $0.79(0.14)$ & $1.67(0.25)$ & $0.93(0.24)$ & $<0.001$ & $<0.0005$ & $>0.05$ & $<0.01$ \\
\hline $10^{-9}$ & $10^{-6}$ & 12 & $2.15(0.38)$ & $0.84(0.57)$ & $1.88(0.28)$ & $1.31(0.39)$ & $0.27(0.10)$ & $<0.025$ & $<0.0025$ & $>0.05$ & $>0.05$ \\
\hline 0 & $10^{-6}$ & 6 & $2.43(0.37)$ & $1.41(0.16)$ & $1.54(0.51)$ & $1.02(0.38)$ & $0.89(0.33)$ & $>0.05$ & $>0.05$ & $>0.05$ & $>0.05$ \\
\hline $10^{-9}$ & $10^{-5}$ & 12 & $2.06(0.28)$ & $1.45(0.19)$ & $2.08(0.46)$ & $0.61(0.14)$ & $-0.02(0.01)$ & $>0.05$ & $>0.05$ & $>0.05$ & $>0.05$ \\
\hline 0 & $10^{-5}$ & 6 & $1.51(0.60)$ & $1.38(0.57)$ & $1.20(0.54)$ & $0.13(0.04)$ & $0.31(0.12)$ & $>0.05$ & $>0.05$ & $>0.05$ & $>0.05$ \\
\hline Untreated con & ntrols & 12 & $1.59(0.20)$ & $1.06(0.17)$ & $0.96(0.28)$ & $0.53(0.17)$ & $0.63(0.21)$ & $>0.05$ & $>0.05$ & $>0.05$ & $>0.05$ \\
\hline
\end{tabular}

All values are mean (SEM). 
$10^{-6} \mathrm{M}$ amiloride and abolished by $10^{-5} \mathrm{M}$ amiloride.

\section{Discussion}

The results presented here show that glucagon at concentrations between $10^{-11} \mathrm{M}$ and $10^{-9} \mathrm{M}$ could reduce lung liquid production or produce reabsorption in vitro by lungs from fetal guinea pigs. The responses were linearly related to the log dose $\left(r^{2}=0.94\right)$, and the greatest number of preparations that turned to reabsorption were seen at the highest concentration. The theoretical threshold indicated by the log dose-response curve was low $\left(4 \times 10^{-15} \mathrm{M}\right)$, but effects could not be shown to be significant until glucagon reached $10^{-11} \mathrm{M}$; nevertheless, the preparations were notably sensitive. The responses appeared to depend on an amiloride sensitive $\mathrm{Na}^{+}$based reabsorptive system, as those at the most effective concentration of glucagon tested $\left(10^{-9} \mathrm{M}\right)$ appeared to be reduced by $10^{-6} \mathrm{M}$ amiloride and were abolished by $10^{-5} \mathrm{M}$ amiloride.

These results suggest a new role for glucagon. An effect in activating lung liquid reabsorption at the time of birth would be reasonable for many reasons. Like other activators of reabsorption, such as adrenaline and AVP, glucagon is a powerful activator of the adenylate cyclase system, and cAMP, its analogues, and forskolin are powerful stimulators of lung fluid reabsorption in fetal sheep and guinea pigs ${ }^{16}$; in fact, in our in vitro preparations, forskolin, a direct stimulator of adenylate cyclase, produced the most powerful reabsorptions yet seen. ${ }^{16}$ As pointed out already, glucagon was central to the discovery of the adenylate cyclase system, ${ }^{17}{ }^{18}$ and it is hardly surprising that it may promote drainage of the newborn lung; however, no study of this has ever been made.

Despite its clear effects, we must consider whether there is sufficient plasma glucagon to have a physiological effect at the time of birth. In fact, glucagon, like adrenaline and AVP, surges to high plasma levels just after birth. Concentrations in various species lie mainly between $10^{-10} \mathrm{M}$ and $10^{-9} \mathrm{M}$ glucagon: rat, $(2.6-3.4) \times 10^{-10} \mathrm{M}^{19} 27$ rabbit, $1.78 \times 10^{-10}$ $\mathrm{M}^{20}$; sheep, $0.68 \times 10^{-10} \mathrm{M}^{21}$; human, (0.4-4.6) $\times 10^{-10} \mathrm{M}^{22} 27-29$. The clearest data, those for sheep, show a rapid rise in the plasma immediately after cutting of the umbilical cord, and, although levels may halve within an hour in sheep, or within 24 hours in rats, they can remain elevated for many days during suckling. ${ }^{2130}$ Nevertheless, the reduction after the initial surge implies that some plasma levels quoted, especially in humans, may have been too late to catch the true maximum in the blood. Therefore $10^{-10} \mathrm{M}$ plasma glucagon is probably a conservative estimate, and values up to $10^{-9} \mathrm{M}$ are reasonable. In our studies, $10^{-10}$ $\mathrm{M}$ glucagon reduced lung liquid production by 70 (6) \% , and $10^{-9} \mathrm{M}$ resulted in a 90 (11)\% fall, with 12 out of 30 preparations reabsorbing fluid. Therefore, our results could reflect the true physiological situation.

In addition, responses at birth would be far greater for the following reasons. (a) It is well known that responses involving lung liquid and the adenylate cyclase system mature and increase considerably near birth. This has been seen for responses to adrenaline, AVP, cAMP itself, and to expansion. ${ }^{131-33}$ Our fetuses were relatively young in such terms; even so, strong reabsorption did occur (fig 3A). There was no evidence for maturational change within our groups, because of the narrow age range chosen, a deliberate selection to allow results to be combined and based on many individuals. The only indication of such changes comes from four notably small fetuses, in which the effect appeared to arise around 65 g body weight. Nevertheless, in another organ, the liver of the fetal guinea pig, increased coupling of glucagon receptors occurs remarkably late, probably only on the day of birth and in the newborn, ${ }^{34}$ therefore large responses of the lungs may also occur late, later than the preparations studied here.

(b) In vivo, responses would be augmented by colloid osmotic effects, which were absent from our in vitro preparations. This also implies that those in vitro preparations that only stopped production in our experiments could be expected to reabsorb fluid in the intact newborn.

(c) In vivo, the effects may form part of a far more complex and effective system, and be augmented through the adrenal medulla. Glucagon has been shown to release catecholamines from adult adrenals. ${ }^{35}{ }^{36}$ In its turn, adrenaline can stimulate fluid reabsorption, and in our in vitro preparations, noradrenaline can act similarly. ${ }^{13}$ Therefore, in the intact animal, glucagon may act directly on the lungs, but also indirectly through the adrenal medulla. In our isolated lungs, the indirect effect through the adrenals would not be seen. However, it is also possible that glucagon may release catecholamines within the pulmonary tissue; acetylcholine stimulates fluid reabsorption in this way. ${ }^{12}$ These observations raise interesting possibilities: catecholamines can release glucagon in fetuses of rats and sheep, and glucagon can also release catecholamines, so that a powerful self activating cycle may exist. ${ }^{37}$ However, the concentration of glucagon needed to release catecholamines is usually high, as judged by work in adults. ${ }^{36}$ Therefore this positive feedback could only work if the adrenals of neonates were notably sensitive to glucagon.

Glucagon appears to act through the same amiloride sensitive $\mathrm{Na}^{+}$based reabsorptive system as activated by adrenaline in fetal sheep, by AVP in fetal sheep and guinea pigs, and by aldosterone in the guinea pig. ${ }^{15632}$ Our results for glucagon are closely similar to those for aldosterone. Responses produced by the highest concentration of glucagon appeared to be reduced by almost half by $10^{-6} \mathrm{M}$ amiloride, and responses were abolished in some preparations. Although this low concentration of amiloride did not abolish all responses, the overall reduction in their magnitude was significant $(p<0.05)$; therefore the $\mathrm{Na}^{+}$channel blocker did have some effect. In contrast, at $10^{-5} \mathrm{M}$ amiloride all responses were abolished, and 
ANOVA showed that the difference was significant at $\mathrm{p}<0.01$. If the comparison were made with all the experiments with $10^{-9} \mathrm{M}$ glucagon from both sets of amiloride studies ( $\mathrm{n}=24$; figs $3 \mathrm{~A}$ and $4 \mathrm{~A}$ ), the difference becomes highly significant at $p<0.0025$. This result was notable; work on fetal sheep has needed amiloride at much greater concentrations to give clear results (at or above $10^{-4}$ M). ${ }^{15}$ Therefore the levels used here may be considered relatively conservative. Nevertheless, at concentrations above $10^{-6} \mathrm{M}$, amiloride starts to have effects beyond simple blockage of sodium channels, effects such as inhibition of $\mathrm{Na}^{+} / \mathrm{H}^{+}$exchange, and at $10^{-3} \mathrm{M}$, it can slow the fundamental $\mathrm{Na}^{+} / \mathrm{K}^{+}$ATPase. ${ }^{39}$ However, our results for $10^{-6} \mathrm{M}$ amiloride suggest that $\mathrm{Na}^{+}$channels are involved, and the total inhibition at $10^{-5} \mathrm{M}$ amiloride shows that the classical $\mathrm{Na}^{+}$based transport system is responsible for the fluid reabsorption.

The effects of glucagon may help to explain the failure of $\beta$-adrenoreceptor antagonists to prevent fluid reabsorption during natural deliveries: the irreversible $\beta$-blocker bromacetylprenolomenthane fails to stop fluid clearance in rabbits either at or after delivery, ${ }^{40}$ and propranolol fails similarly during spontaneous labour in chronic fetal sheep. ${ }^{41}$ In addition, propranolol cannot prevent slowing of fluid production during moderate asphyxia in fetal sheep, and asphyxia is often a complicating factor during vaginal deliveries. ${ }^{42}$ A reabsorptive mechanism independent of $\beta$-adrenoreceptors is needed, and, together with effects of lung expansion, ${ }^{33}$ glucagon may help to fill this need.

An effect of glucagon on lung liquid may prove a major function. Its traditional role in liberating glucose stores at birth has been brought into question. It requires high levels of glucagon to induce glucose generation by the liver of near term fetal guinea pigs, in which receptor numbers are low and the receptoradenylate cyclase system is insensitive..$^{34} 44$ There is similar insensitivity in terms of generation of cAMP in the rat. ${ }^{34}$ In contrast, the reactions of the fetal lungs appear to take place at physiological concentrations. Therefore the surge of glucagon at birth may prove more important to the lungs than to its traditional target organ, the liver.

Finally, it may be significant that the surge of glucagon at birth fails in infants of diabetic mothers, and these infants show a high incidence of respiratory distress syndrome. ${ }^{42}$ Glucagon at high levels is already in clinical use for diagnosing pheochromocytoma ${ }^{36}$; its ability, at far lower levels, to liberate cAMP, which can not only remove lung liquid but also stimulate surfactants, ${ }^{45}$ suggests that it may be considered for possible use in problems of the newborn lung. This is a particularly attractive possibility, as glucagon is a natural constituent of the body, not a drug, and its potential side effect of raising blood glucose could be expected to be weak, and probably of little disadvantage.
We wish to thank David Kojwang for assistance during these studies, Beverly Chua for help with the figures, and the National Research Council of Canada for Operating Grant 582-584 (AMP).

1 Strang LB. Fetal lung liquid: secretion and reabsorption. Physiol Rev 1991;71:991-1016.

2 Aherne W, Dawkins MJR. The removal of fluid from the pulmonary airways after birth and the effect of this on prematurity and prenatal hypoxia. Biol Neonat 1964;7:21429.

3 Adams FH, Yanagisawa M, Kuzela D, Martinek H. The disappearance of fetal lung fluid following birth. F Pediatr 1971;78:837-43.

$4 \mathrm{DeSa}$ DJ. Pulmonary fluid content in infants with respiratory distress. $\mathcal{F}$ Pathol 1969;97:469-79.

5 Cassin S, Perks AM. Amiloride inhibits arginine vasopressin-induced decrease in fetal lung liquid secretion vasopressin-induced decrease in

6 Perks AM, Stockbrocks M, Chuang DC, Vonder Muhll I, Kindler PW. Lung-liquid production in vitro by lungs from fetal guinea pigs: effects of amiloride on responses to aldosterone. Canadian fournal of Zoology 1997;75:114754.

7 Perks AM, Cassin S. The rate of production of lung liquid in fetal goats, and the effect of expansion of the lungs. fournal of Developmental Physiology 1985;7:149-60.

8 Garrad P, Perks AM. The effects of temperature change on lung liquid production by in vitro lungs from fetal guinea pigs. Fournal of Developmental Physiology 1990;14:109-14.

9 Perks AM, Kwok YN, McIntosh CHS, Ruiz T, Kindler PM. Changes in somatostatin-like immunoreactivity in lungs
from perinatal guinea pigs, and the effects of from perinatal guinea pigs, and the effects of Somatostatin-14 on lung liquid productio
Developmental Physiology 1992;18:151-9.

10 Chua B, Perks AM. The effect of dopamine on lung liquid production by in vitro lungs from foetal guinea pigs. $\mathcal{F}$ Physiol (Lond) 1998;513:283-94.

11 Chua B, Perks AM. The pulmonary neuroendocrine system and drainage of the fetal lung: effects of serotonin. Gen Comp Endocrinol 1999;113:374-87.

2 Woods BA, Ng W, Thakorlal, D, Perks AM. The effects of acetyl choline on lung liquid production by in vitro lungs from fetal guinea pigs. Can $\mathcal{f}$ Physiol Pharmacol 1996;74:918-27.

13 Doe S, Woods B, Perks AM. The effects of norepinephrine on lung liquid production by in vitro lungs from fetal guinea pigs. Can f Physiol Pharmacol 1998;76:967-74.

14 Brown LAS, Longmore WJ. Adrenergic and cholinergic regulation of lung surfactant secretion in isolated perfused rat lung and in the alveolar type II cell in culture. $\mathcal{F}$ Biol Chem 1981;256:66-72.

15 Jard S, Roy C, Rajerison R, Butler D, Guillon G. Vasopressin -sensitive adenyl cyclase from the mammalian kidney: mechanics of activation. In: Nicolan C, Paraf A, eds. Proceedings in life sciences, structural and kinetic approach to plasma membrane functions. Berlin: Springer-Verlag 1977:173-87.

16 Kindler PW, Ziabakhsh S, Perks AM. Effects of cAMP, its analogues, and forskolin on lung fluid production by in vitro lung preparations from fetal guinea pigs. Can $\mathcal{f}$ Physiol Pharmacol 1992;70:330-7.

17 Rall TW, Sutherland EW. Formation of a cyclic adenine ribonucleotide by tissue particles. $f$ Biol Chem 1958;232:1065-76

18 Rodbell $\mathrm{M}$. The actions of glucagon at its receptor: regulation of adenylate cyclase. In: Lefebvre PJ, ed. Glucagon I. tion of adenylate cyclase. In: Lefebvre

19 Girard JR, Bal D, Assan R. Glucagon secretion during the early postnatal period in the rat Horm Metab Res early postnatal

20 Callikan S, Farre P, Pegorier JP, Marliss EB, Assan R, Girard JR. Fuel metabolism in fasted newborn rabbits. Fournal of Developmental Physiology 1979;1:267-81.

21 Grajwer LA, Sperling MA, Sack J, Fisher DA. Possible mechanisms and significance of the neonatal surge in glucagon secretion: studies in newborn lambs. Pediatr Res 977;11:833-6.

22 Bloom SR, Johnston DI. Failure of glucagon release in infants of diabetic mothers. BMF 1972;4:453-4.

23 Göke R, Kolligs F, Richter G, Lankat-Buttgereit B, Göke B. Solubilization of active receptors for glucagon-like peptide-1 (7-36) amide from rat lung membranes. Am $\mathcal{F}$ Physiol 1993;264:L146-52.

24 Campos RV, Lee YC, Drucker DJ. Divergent tissue-specific and developmental expression of receptors for glucagon and glucagon-like

25 Cassin S, Perks AM. Studies of factors which stimulate lung fluid secretion in fetal goats. Fournal of Developmental Physiology 1982;4:311-25.

26 Perks AM, Dore JJ, Dyer R, et al. Fluid production by in vitro lungs from fetal guinea pigs. Can $\mathcal{F}$ Physiol Pharmacol 1990;68:505-13.

27 Blazquez ET, Sugase M, Blazquez M, Foa PP. Neonatal changes in the concentration of rat liver cyclic AMP and of serum glucose, FFA, insulin, pancreatic and total glucagon in man and in the rat. $\mathcal{F}$ Lab Clin Med 1974;83:957-67.

28 Luyckx A, Massi-Bendetti F, Falorni A, Lefèbvre PJ. Presence of pancreatic glucagon in the portal plasma of human neontes. Differences in the insulin and glucagon human neontes. Differences in the insulin and glucagon responses to glucose between normal infants and
diabetic mothers. Diabetologia 1972;8:296-300. 
29 Sperling MA, Delamater PV, Phelps, D, Fiser RH, Oh W, Fisher DA. Spontaneous and amino acid stimulated glucagon secretion in the immediate postnatal period. $\mathcal{F}$ Clin Invest 1974,53:1159-66.

30 Girard JR, Kervran A, Assan R. Functional maturation of the A cell in the rat. In: Camarini-Davalos RA, Cole HS, eds. Early diabetes in early life. London, New York: Academic Press, 1975:57-71.

31 Perks AM, Cassin S. The effects of arginine vasopressin and epinephrine on lung liquid production in fetal goats. Can $\mathcal{F}$ Physiol Pharmacol 1989;67:491-8.

32 Perks AM, Kindler PM, Marshall J, Woods B, Craddock M, Vonder Muhll I. Lung liquid production by in vitro lungs from fetal guinea pigs: effects of arginine vasopressin and arginine vasotocin. Fournal of Developmental Physiology 1993;19:203-13.

33 Garrad Nelson P, Perks AM. Effects of lung expansion on lung liquid production in vitro by lungs from fetal guinea
pigs. I. Basic studies and the effects of amiloride and propranolol. Reprod Fertil Dev 1996;8:335-46.

34 Ganguli S, Sinha M, Sperling MA, Banach W, Hsiung, G. Ontogeny of insulin and glucagon receptors and the adenylate cyclase system in guinea pig liver. Pediatr Res 1984;18:558-65.

35 Scian LF, Westermann CD, Verdesca AS, Hilton JG. Adrenocortical and medullory effects of glucagon. $\mathrm{Am} \mathcal{f}$ Physiol 1960;199:867-70.

36 Lefèbvre PJ, Luyckx AS. Glucagon and catecholamines. In: Lefèbvre PJ, ed. Glucagon II. Berlin: Springer-Verlag, 1983:537-43.

37 Girard JR, Kervran A, Soufflet E, Assan R. Factors affecting the secretion of insulin and glucagon by the rat fetus. Diabetes 1974;23:310-17.
38 Sperling MA, Christensen RA, Gangluli S, Anand R. Adrenergic modulation of pancreatic hormone secretion in utero: studies in fetal sheep. Pediatr Res 1980;14: 203-8.

39 Soltoff SP, Mandal LJ. Amiloride directly inhibits the Na, K-ATPase activity of rabbit kidney proximal tubules. Science 1983;220:957-9.

40 McDonald JV, Gonzales LW, Ballard PL, Pitha J, Roberts JM. Lung $\beta$-adrenoreceptor blockade affects perinatal surfactant release but not lung water. F Appl Physiol 1986;60:1727-33.

41 Chapman DL, Carlton DP, Nielson DW, Cummings JJ, Poulain FP, Bland RD. Changes in lung liquid during spontaneous labor in fetal sheep. f Appl Physiol 1994;76:523-30.

42 Hooper SB, Harding R. Effect of $\beta$-adrenergic blockade on lung liquid secretion during fetal asphyxia $\mathrm{Am}$ f Physiol 1989;247:R705-10.

43 Blazquez E, Rubalcava B, Montesano R, Orci L, Unger RH. Development of insulin and glucagon binding and the adenylate cyclase response in liver membranes of prenatal, postnatal and adult rat: evidence for glucagon resistance. Endocrinology 1976;98:1014-23.

44 Jones CT. Control of glucose metabolism in the perinatal period. Fournal of Developmental Physiology 1991;15: $81-9$.

45 Aberhard EE, Scott ML, Barret CT, Kaplan SA. Effects of cyclic AMP analogues and phosphodiesterase inhibitors on phospholipid biosynthesis in fetal type II pneumocytes. Biochim Biophys Acta 1984;803:29-38.

\title{
Sneha-India and the International Council for Research into the Fetal Origins of Adult Disease
}

\section{First World Congress: Fetal Origins of Adult Disease}

\author{
Sponsored by the British Medical fournal \\ 2-4 February 2001, Mumbai, India
}

Poor fetal growth is associated with an increased risk of adult cardiovascular disease and diabetes, which has led to the hypothesis that these disorders originate through undernutrition in utero. Evidence also links fetal growth with later osteoporosis, neurological and psychiatric disease, hormone related cancers and atopy. This conference will bring together, for the first time, clinicians, epidemiologists, and basic scientists working in this field.

Topics include:

Cardiovascular disease

Diabetes

Cancer

Osteoporosis

Asthma

Ageing

Mental Health

Maternal nutrition

Control of fetal growth

Hormonal programming

Immune function

Strategies for preventing disease

Plenary speakers include: Claude Lenfant (USA), Nick Hales (UK), Christopher Martyne (UK), Chittaranjan Yajnik (India), Michael Meaney (Canada), Jeffrey Robinson (Australia), Jane Harding (New Zealand), Kent Thornburg (USA), John Challis (Canada), Alan Jackson (UK), Keith Godfrey (UK), Patrick Bateson (UK), Peter Gluckman (New Zealand).

Scientific committee chairman: David Barker, Southampton, UK

Organising committee chairman: Anand Pandit, Pune, India

Further details from: Ms Alifiya S Motiwala (tel: +91 22 651 6439/645 6763; fax: +91 22 6516438; email: mrcssc@vsnl.com).

Alternatively, fill in the "Yes, I am interested" reply slip on our website: www.sneha-india.org 